University of Montana

ScholarWorks at University of Montana

Graduate Student Theses, Dissertations, \&

Professional Papers

1968

\title{
Temperature regulation in the white-tailed ptarmigan Lagopus leucurus
}

Richard Evan Johnson

The University of Montana

Follow this and additional works at: https://scholarworks.umt.edu/etd

Let us know how access to this document benefits you.

\section{Recommended Citation}

Johnson, Richard Evan, "Temperature regulation in the white-tailed ptarmigan Lagopus leucurus" (1968). Graduate Student Theses, Dissertations, \& Professional Papers. 6898.

https://scholarworks.umt.edu/etd/6898

This Thesis is brought to you for free and open access by the Graduate School at ScholarWorks at University of Montana. It has been accepted for inclusion in Graduate Student Theses, Dissertations, \& Professional Papers by an authorized administrator of ScholarWorks at University of Montana. For more information, please contact

scholarworks@mso.umt.edu. 


\section{TEAPERATURE RBGULATION IN THE WHITB-TAILED PTARAIGAN, \\ Lagopus Leucurus}

by

RICHARD E. JOHNSON

B.s., Dnivernity of Calffornia, 2958

Presented in partial fulfiliment of the requirements for the degree of Master of Science in 2oology

UNIVERSITY OF MONTANA

2968

Approved by:

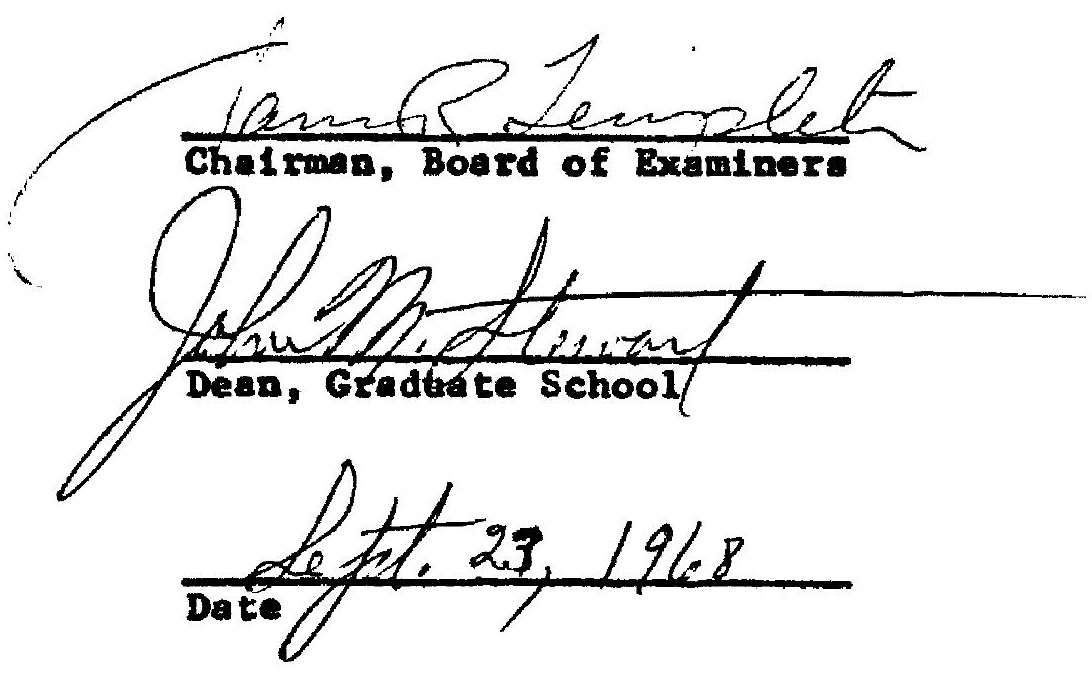


UMI Number: EP37699

\author{
All rights reserved
}

INFORMATION TO ALL USERS

The quality of this reproduction is dependent upon the quality of the copy submitted.

In the unlikely event that the author did not send a compiete manuscript and there are missing pages, these will be noted. Also, if material had to be removed, a note will indicate the deletion.

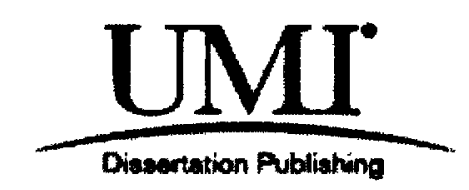

UMI EP37699

Published by ProQuest LLC (2013). Copyright in the Dissertation held by the Author.

Microform Edition (-) ProQuest LLC.

All rights reserved. This work is protected against unauthorized copying under Title 17, United States Code

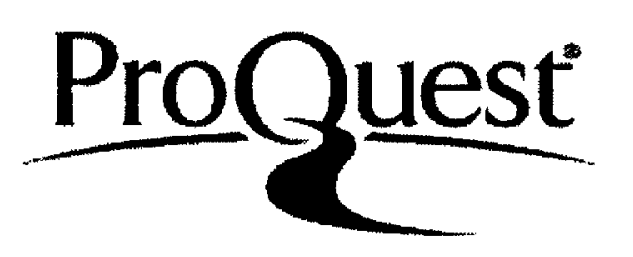

ProQuest LLC.

789 East Eisenhower Parkway

P.O. Box 1346

Ann Arbor, MI 48106 - 1346 
IMTRODUCTYOR ...................................

Materatals atrd merhós. ..........................

Oxgen coneurption ...........................

Evaporat17e Water Losa ....................... 14

Body Terperature .............................. 16

Drscusston .................................. 28

Oxyer Coneraption .......................... 18

Insuretion ................................ 19

Iraporat1re covilng. ......................... 22

Body Torgeraturo .............................. 23

Environmental Relations. ...................... 26

вUMARY. ..................................... 28

mTtgRature cITED ............................... 29 


\section{ACKNOWLEDGMEHTS}

I am Indebted to Dr. James R. Templeton. Department of Zoology. Unirersity of Kontana, for hIs guldance throughout the study and to Dr. Robert s. Hoffmann. Department of Zoologs, Unlversity of Montana, and Dr. Paul Licht, Department of Zoosogy. University of California. for critically reading the manuscript, and to Glacier Iational Park for generously providing research space and other assistance. Th1s research ves supported by a National Selence Founcation Cooperative Fellowsip. 


\section{LIST OF TABLES}

Table

Page

1. Body Temperatures et Amblent Tewperatures Outs1de the

Thermoneutrel zone ......................... 20

2. Experimental and Expected Metabalio Ratea. . . . . . . * 21

3. Body Terperatures of Ptarmigat ................... 25 


\section{I.IST OF PIOURES}

Pigame

1. Variation in lietabalias with Temperature for

Imenty-four Fasted inite-telled Ptarmi gan . ......... 12

2 Evaporetive Dater Ioss as Fmotion of Amblent

Fenperature for B1xtoen Whito-telled Ptermigan. . . . . 15

3. Evaporative Cooling as a Tunction of Ambient

Temperature for 81xteen Ih1te-talled Ptarmigan. . . . . 17 
ImTRODUCTIOR

Interest in the grouse family (Tetraonidac) has resulted in numerous population and behavior otudies with particular emphas is upon game manegement. Bpeciul Importance has been placed upon factore which control populetion levele and huctuations. Mang authors have IInked weather, and particularly amblent temperatures, with population nuctuations in these birde. Cold, late opring and sumer tedperatures are often correlated fith lov eroube populations in the fall and this 18 ubually caused by high juvenile wortallty (Blank and Asb. 295T Myrberget, Benenov-Taln-Shanek, 2965, all in Jenkine, Watson, and Miller, 19631 CFlasey in Bump, 2947, Edminster, 294T, HBglund, 2952, Moran, 1954 Laren and Lahey, 2958, Doz $20 y$ and Kabat, 1960, Riteey and Eiwards, 1963 ). Whlle Low al temperatures in apring can affect the young birds directiy. 16 can also affect them indireetis by limiting theif food eupply (s11vonen, 1957, Jenking, Watson, and H111er, 1963 ; M112er, Jenkins, and Wetson. 2966, Leck. 1966).

Both high and low winter terperatures have been correlated with mortality of edult and Imature birds. Bigh vinter tewgratures have been corralated with low Bupfed Grouse populations in Minnesota and Wisconsin, perbeps through effects of resuiting enerueted onow (Larsed and Labey. 2958, Dornes and Kabat, 1960). Hovever, there 1s coneiderable debate ebout the slgnifloance of oncrusted snow (Clarke, 2936 Criseer in Bup. 2947, Edminater. 29473 Grenge, 1949. Lareen and Lahey. 1958). Lor vinter temperatures were correleted with $10 v$ spring populatlons of the seme epecter in Hev York (Crtasey in Bump. 194T). 
All of these studies have related longuterm veatber data to popum lation changes but no one has examined individuals of one age group at a particular season in order to deterwine speciflcally what temperature adaptations and problems do exist. The present etudy examines temperature regulation of breeding adult Wite-talled Ptarmigan (Lapopus leucurug) in Montane.

Ptarmigan are probably basically cold-adapted birds judging rrom the1r northern diatribution and arctie-alpine hebltat. Three species of ptermigen occur in Canads and Alaske, but of these only the White-talled Ptarmigan occurs as a breeding bird In the United states. Hero it is IInited to the alpine zone of the Rocky Mountains and the Cascade Range. In Montana this species may encounter amblent temperatures belov $-45^{\circ} \mathrm{C}$. In rinter (U.8. Dept. of AGr1., 1941). Ptaraigan use counter-current heat exchange in their legs and unlike most birde. ptarmigan have reathered reet (Irving and Krog, 1955). These tro edaptations reduce heat 108 considerably. Cold is also an important factor in thelr environwent In the sumer. For exanple, amblent temperatures rrequently reach reezIng and as much as two feet of gnov may fall during the nesting geason in Montane, Hens will remain on the nest, beconing completely burled, during such a snowrall (Nethersole-Thompaon, 1939; Edwarde, 1957; Choate, 2960) and egge can vithotend cooling to near rreezlng temperatures (Berth. 1949). In spite of these adaptations. Incubation success is lovered and chick mortality is increased during heavy enowfall and hall (Choate. 2963a, b).

On the other hand, the open alpine habltat also exposes the ptarmigan to considerable radiant heating as indicated by aumer ground 
temperatures which may exceed alr temperatures by $20^{\circ} \mathrm{C}$. (Swan, 1952 ; Verbeek, 2965; personal obs.). High alf temperaturea may play a role in deteraining the geographic alatribution and habitat selection of the White-talled Ptarnigan during the breeding season in the United States. The excellent doral insulation of the ptarmigan no doubt offers considerable protection from solar radiation, but, in apite of this, birds in the sun begin to pant at reletively lov alr temperatures (Bradbury. 1915: Balley and Ba1ley, 2918; Taylor and Shaw, 1927). In Pact, these birds may pant at air temperatures as $10 \mathrm{w}$ as $21^{\circ} \mathrm{C}$. (Choste. 1963 at personal obs.) which auggests that the totel insulation prevents loss of body heat to this relatively cool alf. On Logan Pass, Glacier National Park. Montana, where birds used in this etudy vere obtalned, alr temperatures reached or exceeded $21^{\circ} \mathrm{C}$. on approximately $40 \%$ of the days between midJune and the end of August in 1960, 2961, end 1962 and reached a maximum of $32.0^{\circ} \mathrm{C}$. In 1961 (Choate. 1963a). Incubating hens on exposed neste would probably experience the greatest temperature stress and setting bens have been observed panting on vara days (Choate, 1960). It is perhaps significant that Choate (1960) found that the majority of nests were at least partialiy protected from solar radiation by a large rock or bueh.

In August Mocklng birds wove to cooler locations (shade, snow) and on hot days often congregate under snowbanks. Hens with young ure In molst meadows along water courses and beside snowbanks where vesntetion 18 at111 green and tender and the alcroenvironment is cool (Choate. 2963 as parsonal obs.). 
Thü, two behaviorel patterne, movenent to cool lucations on hot days and selection of protected nest sites, ald then in aroiding high temperatures. Ptarmigan are round at the highest elevations in the soutbernmogt part of their range and consequentiy radiant heating vould be the greategt there. In these locations beharioral patterns way be exceedingly luportant and the leck of protected locations for nests or permanent snov prorlaing a cooler weroclimate on hot days may preclude the presence of this opecies especially if it is heavily insulated. Logan Pass is at the lover elevational limit of breoding birds in Olacier NetLonal Park (Parratt, 1954 ; porsonel obs.) and a largo anow pack remaining frow an earlier glacier and abundant shede beneath Mount Clements provide a cool microenvironment which 1s ut1lised on hot days. Glaclers and shade are avallable at all other locations where ptaralgan occur at simllàr lor elevations. Ptarmigan seen to be absent from 1milar, ppparentiy desirable habitats at this elevation (Aster Park. Parad1se Park) that lack permanent snov or elaclers. Ptarmigan at higher elevetions are not alvays asaociated vith onow and lce though th1: assuolation 13 at12: comon. Ftarmigan occur an far bouth as New Mexlco at much hlgher elevationa but these areas have not been Inveatigated.

The White-tailed Ptarmigan appears edepted to cold climate. The present study seeks to determine the role of physiological adaptation to the alpine environment and, if these adaptetiona exist, whether they precluce its existing elsewhere.

To accomplish thls, motabolie rate and heat $108 \mathrm{~s}$ by eraporation of vater vere measured over a vide renge of temperatures in the 
laboratory on birds taken rom Logan Pass. These data are compared vith data frow other bird species and to temperature data ron Iogan Pass. Metabolism can be weasured directiy by measuring heat production or Indirectiy by measuring elther oxygen consumption or carbon aloxide production. The indirect method is much olmpler and is nore comonly used. Precise determination of metabolie rate by the indirect method requires measurement of both oxygen and carbon dioxide as well as urinary altrogen excretion. These data allow conputation of the resplratory quotient intch is necessary to determine the exect celoris equivalent of the oxygen conmued. However urlbary nitrogen excretion is usually not measured elnce $1 t$ í deflcult to datermine in birds and is of $21 t t 20$ eIgniflcance in post-absorptive birda (KIng and Farner, 1961). It is. nov atandard procedure to assume a mean calorlo equivalent of $4.8 \mathrm{cal} / \mathrm{cc}$ or oxygen and thus alspense with measurements of carbon dioxide and urinary nitrogen. Thls latter procedure was followed in this study. Por blrds this usuelly produces excellent results but occaslonally large errors have resulted. The reasons for this are unknown (King and Farner, 2961).

Standard metabol10 rates are understandably greater in large animals than in small anibals but this relationship is not direct. When examined on a per gram bas1s, hoverer. netabolisw usualiy increass as body afze decreases. Several formulae have been proposed to describe this relationship in birda.

The Brody-Proctor equation developed in 1932 describes the relatlonship as nearly as it could be determined from the IInlted data avallable at that time. Witb increasing research, however, it beceme obvious 
that the date fron small passerine birds ald not it the equation developed for large nonpasserine birds and two equations vere suggested: one for small birds and one for laree birde (King and Farner. 1961 ). With the appearance of data fron small nonpasserino birds it becume clear that the alrference observed earlier was really betveen passerine and nompesserlne b1ras and not simply between large and small birds. Pasgerlae blrde have a higher netabolle fate than nonpasserine birds of the sane size, but the rate of increase of metabolio rate with size is the ame for both groups of birde (Lasiewskz and Dawson, 1967). Bcholander, et al. (1950n), end others (see review by king and Farner. 1961) have skown that over a certaln range of temperatures most varmblooded enimal. maintain constant motabolio rates and body temperatures. This means that heat production rensine constant but heat 1088 18 varled by physiological end physical meane thereby keeping body temperature congtant. Heat 208 may be physlologtcaily regulated by rasomotor control of blood alatmibution, evaporative cooling. and by countercurrent heat exchange in appendegeg (Irving and Krog. 1955 , Kahl. 1963) and physically regulated by changes in feather or fur arrangenent (Bcholander. et al. 2950a). This ambient temperature range over whleh netaboilar ramaina constant is referred to as the thermoneutral sone. At the lower limit of the thermoneutral sone, temperatures are reached at which the aningl can no longer maintain 1 ts body temperature by contral of heat 1088 and therefore an increase in wetabolism 18 necessary if, body texperature is to remain constant. This lower Iimft to the thermoneutral sone 18 celled the lower critical temperature. Belor this point metabolisw Increases with decreasing temperature at 
- constant rate and Scholander, et al. (1950a), have shown that this rate 1s proportlonal to the Insulation of the andmal. Thus, if metabolic rate 1. plotted against amblent temperature, the slope of the line at ambleat tempersture below the lower critical temperature is a measure of insuIntion (called conductance) and can be compared with values obtalned from other animals.

Another measurs of invulation often used is insulative value. Th1s 1s computed by dividing the temperature difference between the body temerature and the lover critieal temperature (this afference is called the eritieal thermal armalent) by the stendard metabolic rate (Morxison and T1etz, 2957; Miach, 2960). Both Labulative value ond condustance are computed for the ptarnalgan in order to compare with data arallable for other specles. Insulation can also be measured difoctly by beat transfer atudiea through skins of dead animald (Scholander, et 으. 19503) but these skine not have the same properties as those possassed by living animaia.

If anbient temperatures are 20 vered at $1 \mathrm{ll}$ surther a temperature vill eventually be reached beyond which the enterel can no longer ralse Its metabolism and thereby its heat production to offeet heet 2088 . At this point body temperature will decrease caubing metabollem to decrease and denth soon results. This point is temed the lover lethel temperature. Varfation in this temperature are probebly of adaptive signiflcance, but for data are avaliable in the literature probably because sacriftes of the experimontal onimale is required. As asblent temperatures reach the upper end of the the raoneutral zone. a point is reached at wich amtient temperature equals body 
texperatire. Since heat $10 \mathrm{ss}$ is proportional to the terpers.ture Eradient, uny Increase in amblent tempersture above body temperature will reurit in heat gain by the andmal. Pasaive forms of heat loss (compression of featbers or fur, periphereal vasodilation) which vere effective belov this temperature are not longer uneful. Active heat dissipation ut1lizing eveporative cooling (panting, sveating) is then necessary if the onimal is to maintaln a constant body terperature in apite of the rising ambient temperature. Such active heat loss requires energs and results in an incrase in metabolic rate and thereforo in the metabollc has to be dissipated. Both active heat lons and incrensed metabol1c rate begin at an aviblent temperature someuhat belov the body temperature, which probably reflects the degree to which insulation, -ven when decreased to a minimum, impodes heat 20as. The temperature above whlch metabolism lacrsases is called the upper critical temperature. Whlle it may seem reasonable that a high value would reflect adaptations to a varm eavironent in afferent spectes, this relationship is not clear since upper critfeal temperatumes so far measured do sot appreciubly alfer in epecies from thermaliy afferent habitats. Perbaps the best reasures of Fhyslologlcal alaptation to heat aro eraporative efficlency ad obillty to tolerate hyperthermia. In the present otudy evaporative efflelency wan deterafned for comparison with other spec1es. The parametera of hypertherria vere not neasured hecnuse sucb e otudy woula have required sacrifice of many birds which was not permitted ty the park euthorities. 
MATERIALS AND METHODS

Wh1te-teiled Ptaralgan were obtained wth a hand net on the moadow of Logan Pass at 6,800 to 7,400 teet in Glecler Hational Park. Montane in June through Auguat, 1965. Capt1ve vere transported 18 w1ed to 8t. Mury (4,500 reet) where thoy vere malntained Indoore at approximately $21^{\circ}$ C. In ceges mesaring $51 \times 61 \times 76 \mathrm{~cm}$. They vere supplied with arit, trater for drinking, and food.

Ptaraigen did not adapt readily to captivity and sone indiricuale required force-reeding before aceepting the new diet end conatlons. A Hde variety of naturel foods, comerelal erains, and warket ruite and regetables were tried prior to initiating the study. Heal vorm (Tenebrio 2arvae). apple slloes, and lettuce wero the wot readily accepted, and wost indiridual gained wight on this afet. Twonty-four healthy adult birds everaglng 326 grans in welght (range 275-374 6.) vere studied. B1rds vere velghed before and efter each experiment. Blrds were beld ceptive from flve to ten daya and tben returned to Logan Pase.

Oxygen coneuption of resting birab that were fanted for at least 16 hours the meecured at varloue constant emblent temperatures using a Beckman O-2 paramegnetle oxygen analyser connected to a Brown recording potentioneter. The alf paseed at lov proseure through an open elrcule aratem Vie tygon tubing from an af pump through an equalLalog ohamber. Drierite (anyarous $\mathrm{CesO}_{4}$ ) arying train, a motabolic chamber. a ellea gel drylng train, an Ascarite (sodium bydrate asbestos aboorbent) tratn, Aoweter, and the oxygen annyser. 
Metabolie chanbers were constructed tron rectanguler five galion (28.9 Ilter) cans fitted wth a vire acreen noor (2/2 1 Inch mesh) et $3-5$ en above the bottow. Mineral oll $(2 \mathrm{~cm})$ pleced under the vire gereen covered fecea volded during the experiment procluding contributIon of reeal water to the chamber a1r. Data vero discarded in those ceses where feces lodged on the vereen.

In the type of sotabolic apperatus aescribed above the relative humidty varies with the evaporative weter loos of the bird and with the amblent temperature. Since tbe ereporative efficleacy of an animal 1. affected by the humilty. rapld alr flov of 1600 oc per alnute vas chosen which nalntalned a low and fairiy conetant humidty (1.4 to $7.3 \%$ ). The reletive humidity wa computed by the formula given by Lablewsi (1964) and Lesierrki, et al. (1966a).

Reletire Humidity $=100$ $\left[\frac{\mathrm{MRT}}{\mathrm{V}(0.621)} \theta_{0}\right]$ where

$$
\begin{aligned}
& 4 \text { - mase of rater vapor (gra/min) } \\
& \text { R }=\text { gas eonstant }\left(2.87 \times 106 \mathrm{erg} /{ }^{\circ} \mathrm{K}\right) \\
& \mathrm{T} \text { - amblent temperature }\left({ }^{\circ} \mathrm{K}\right) \\
& V=\cos ^{3} \text { atr/nin. } \\
& 0.621=\text { conetant } \\
& \text { - 1,333 dymes/en }{ }^{2} x \text { atturated rapor presaure }
\end{aligned}
$$

This now rate vas aurrieleat to maintain the oxygen level ebove $20 \%$ and the $\mathrm{CO}_{2}$ level belov one pereent.

Oxgren consurption was computed using the following formule given by Depoces and Hart (1957) for open-ciroult bystems. 


$$
\mathrm{vo}=\mathrm{vE}\left[\frac{\mathrm{PIO}_{2}-\mathrm{PEO}_{2}}{\mathrm{~PB}-\mathrm{PIO}_{2}}\right]
$$

were

$$
\begin{aligned}
& \mathrm{VO}_{2} \text { - oxygen consumption of the anfmal per minute } \\
& \mathrm{VE} \text { - rolume of air noving out of the cage per minute } \\
& \mathrm{PIO}_{2} \text { - partial presaure of oxgen noving lnto the cage } \\
& \mathrm{PEO}_{2} \text { - partial pressure of oxygen noving out of the cage } \\
& \mathrm{PB} \text { - atmospherle pressure }
\end{aligned}
$$

Gas volumes vere corrected to STP. A constant amblent tomperature $\left(\$ 0.3^{\circ} \mathrm{C}.\right)$ was malntalued in the wetabolle chamber by placing lt vithla a temperature control chamber. Metabolic chember temperatures vere measured using a sensitive thermister bridge and therminter probes covered with teflon. Birds wre left in the chambers for at least two hours prior to collecting data and by this time ructuntions in oxgren conaumption were usually not detectiblo. Recordinge vere always cont lnued until varlation in oxygen reading for one hour was $\pm 0.04 \%$ and an averege rate vas computed rrom rates ten equaliy opeced points on the tracing.

Evaporative vater losa wa determined from the velght gals of the -111ce gel drying traln during each exporiment. Two arylng tubes were used for temperatures below $25^{\circ} \mathrm{C}$, and three were used above that temperature. Additional tubes downotream in each caso ware shown not to trap additional vater.

Eveporative vater 108 and oxjhen consumption were measured -imultaneousiy in order to deternine the percentage of motabolle heat disalpated by ereporative coollag at each amblent temperature. Reat 


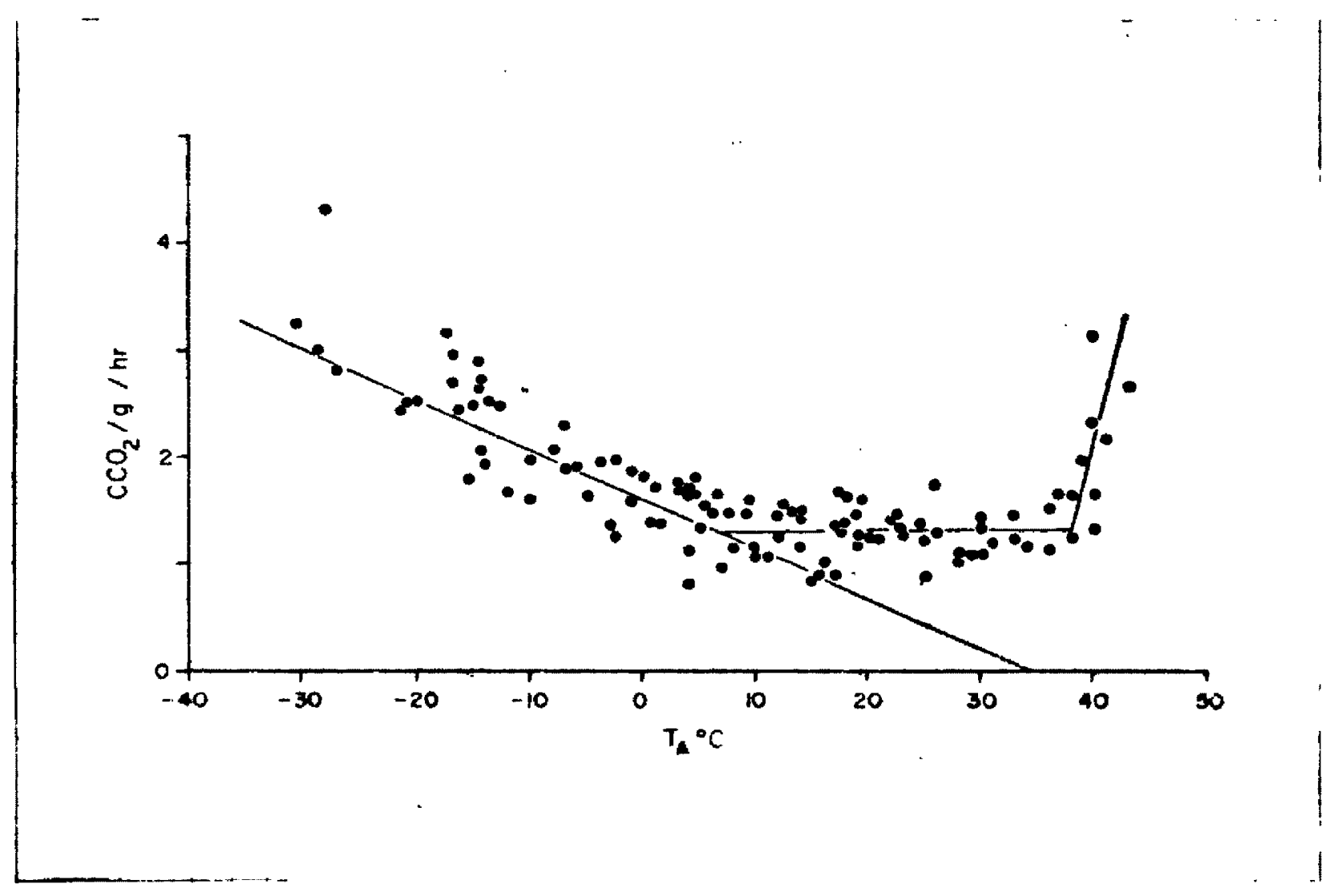

Fis. 1. Variat1oa in wetabol1sm vith temperature for twenty-four fasted White-tailed Ptaral gan. 
Gain and 1080 wa cellewleted from oxg gen consumption and eraporative water 20 a by eseuming aloric equiralont for oxyen of $4.8 \mathrm{cal} / \mathrm{co}$ consumad and atent heat of raporiantion of rater of 0.58 cal $/$ ag eraporeted.

Cloacal tewperaturee vere taken with amall quick regletering thermonter pleced wil into the eloace imediatels after the birds were renowed from the chamber.

\section{RESULTS}

\section{Oxyren Consuregtion}

The relation of oxygen conauription to ambient temperature in the Wrte-talled Ptarnigan durtag eumer to whow in Fig. 1. The netabolle rete vetween amblent temperatures of $\mathrm{h}^{\circ}$ and $36^{\circ} \mathrm{C}$. appeara to be constent and has been taken as the etendera notabolic rate vich equals 2.30 ce $0_{2} /$ gin $\times$ br $(\sigma=0.24)$. Other amblent temperature renges ueing rarloue lover 21 inte betwen $3^{\circ}$ and $12^{\circ}$ yleld nearly ldentical wan metabol1e ratee $(1.27-1.31)$.

4 regreeston $11 \mathrm{ne}\left(\cos 0_{2} / \mathrm{gm} \times \mathrm{hr}=1.6-0.047 \mathrm{t}\right.$. where t $1 \mathrm{~s}$ tomperature in degrees Contigrade) fitted to the points between $2^{\circ}$ and $-18^{\circ} \mathrm{C}$. extrapolates to $34^{\circ} \mathrm{C}$. which 10 belor the 10 ver $21 \mathrm{~m}$ to of normal body temperature. Folnta belov an amblent temperature of $-18^{\circ} \mathrm{C}$. wero not used because there is eridence that these blrds had lovered bodr teuperaturee (see Body Temperature). Polnts belov $-16^{\circ} \mathrm{C}$. describe alightly eteeper curve and poesibly reanted from undetected activits. Blrde tended to be more wetive at these very lov mbient temperatures. 
If the four polnts between $-16^{\circ} \mathrm{C}$. and $-18^{\circ} \mathrm{C}$. are also excluded, the regresslon line becomes $2.7-0.036 \mathrm{t}$ wheh extrapolates to $47.5^{\circ} \mathrm{C}$. The polnt at wich the flrat repreasion line intersected the basal 11ne, $6.5^{\circ} \mathrm{C}$. was taken as tho lover criticel tomperature. A lover criticel temperature of $11.5^{\circ} \mathrm{C}$. 18 obtained using the second regresslon 11ne. Both polate are above the apparent visuel lover critical temperature $\left(4^{\circ} \mathrm{C}.\right)$ used in computing the stendard metabolic rate (see above).

The uppor critical temperature of $38^{\circ} \mathrm{C}$. vas determined by the Intersection of the tasel Ilne and a visually fltted line through pointe In the upper temperature range.

All birds exposed to an amblent temperature of $39^{\circ} \mathrm{C}$. or less for rour bours meintelned contant wetabolle rates and none died. At an ablent of $40^{\circ} \mathrm{C}$. end above. metabolic rates of four birds remalned level or exradually Inereased for one hulf to one hour and then suddenly rose precipltousy. 121 blrds vere removed at thls point and those moanured had elevated body temperatures. One bird at an ambient temperature of $40^{\circ} \mathrm{C}$. meintalned a conetant metabolid rate for five hours. Motabolie ratee obtalned at nlght (1900-2300 hours) dia not difrer frow those obtalned in the day (1000-1800 bours).

\section{Evaporat17e Water Loss}

Evaporative vater lose Increases very sloviy with amblent temperature tron $0^{\circ}$ to $27^{\circ} \mathrm{C}$. and more raplaly above $27^{\circ}$ (F1g. 2 ). Howerer. the onset of panting remalns unknown sinoe the curve appears to be a 


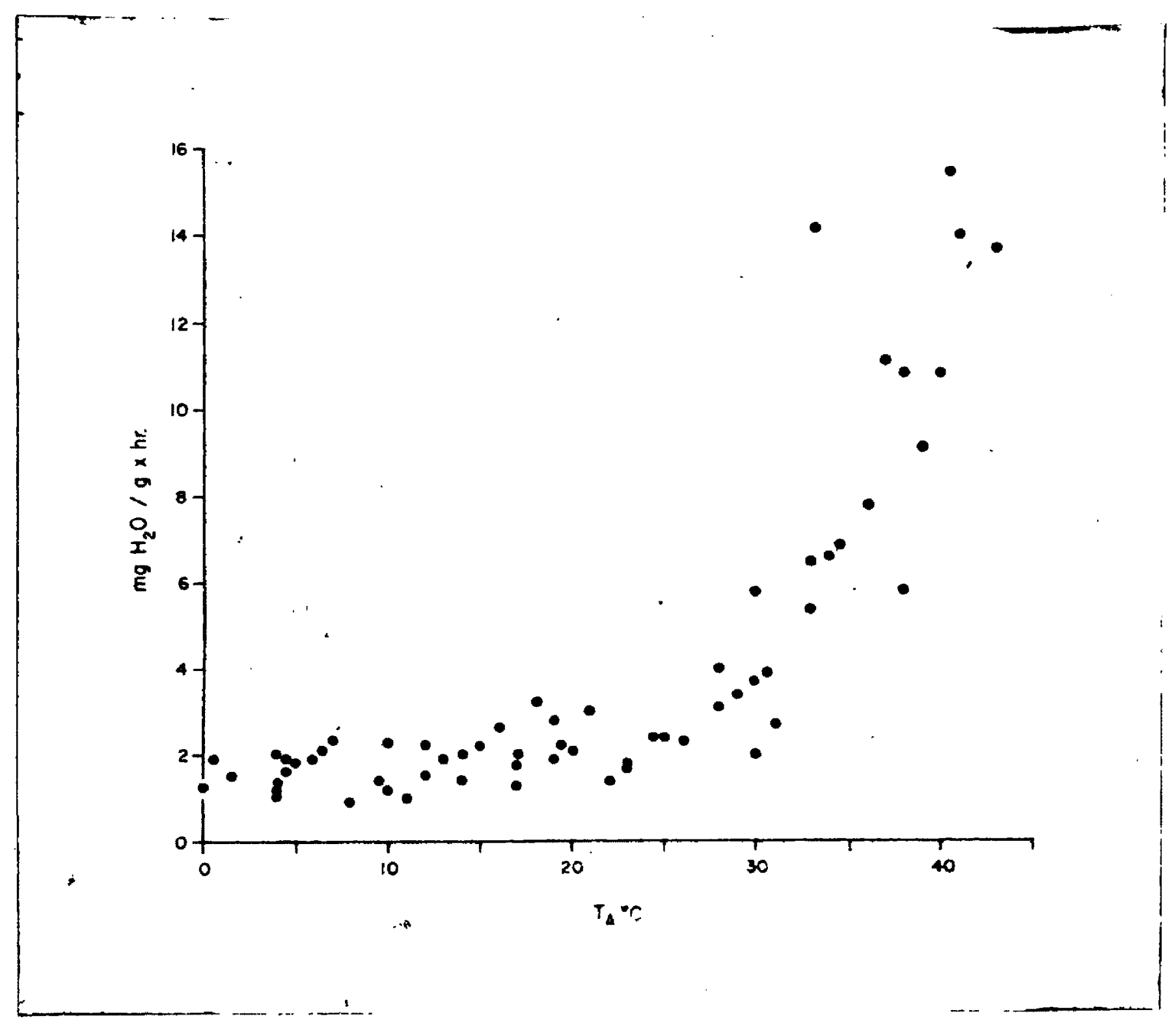

F1g. 2. Evaporat I ve water loss as a runction of ambient temperature for iluteon Whito-talled Ptarmigen. 
continuous runction and panting could not be observed withln the metabollo chember. At hlgh enblent temperaturea White-talled Ptarmigan 1080 no wore than $90 \%$ (one individual) of tbeir metebollo bast by evaporative cooling ( $\mathrm{Fig}, 3$ ).

\section{Body Teaperature}

Inirtymone body temperatures of nine individuns were recorded between lugust 20 and 25. The body temperetures of seven renting birds in eages at an ambiont temperature of $22^{\circ} \mathrm{C}$. areraged $39.9^{\circ}$ and ranged between $38.6^{\circ}$ and $40.3^{\circ} \mathrm{C}$. dur1ng the day and aversged $39.3^{\circ}$ and ranged between $38.0^{\circ}$ and $40.2^{\circ}$ at $8,00 \mathrm{AM}$ when the 11 ghts were turned on in the morning. Body temperatures of soven resting birde vithin the wabollo ahnsber et emblent temparature betveen $6^{\circ}$ and $38^{\circ} \mathrm{C}$. (themoneutral sone) were within the dar range. Iovever one bird at an aublent temperature of $7.5^{\circ} \mathrm{had}$ a body temperature of $36.4^{\circ} \mathrm{C}$. Thil bird maintained a constant metabolle rate for cour hours and eppeared to be healthy at the end of the experiment.

The one body temperature $\left(39.0^{\circ}\right)$ measured within the amblent temperature range botwen $6.5^{\circ}$ and $-17^{\circ} \mathrm{C}$. vas sinilar to those mosured wthin the thermonevtral sone (Table 1). All blras whose wetabolie rates vere measured ( 48 measurenente) in this ablent temperature renge melntalned a conetant eleveted metebolle level for four or wore hours.

None of the sine birds studied at ambient temperatures between $-18^{\circ} \mathrm{C}$. and $-31^{\circ} \mathrm{C}$. could malntaln an elevated notabolle rate for over two hours and four ded after removal from the chamber. The body temperatures of two of these four upon remoral from the chamber were 


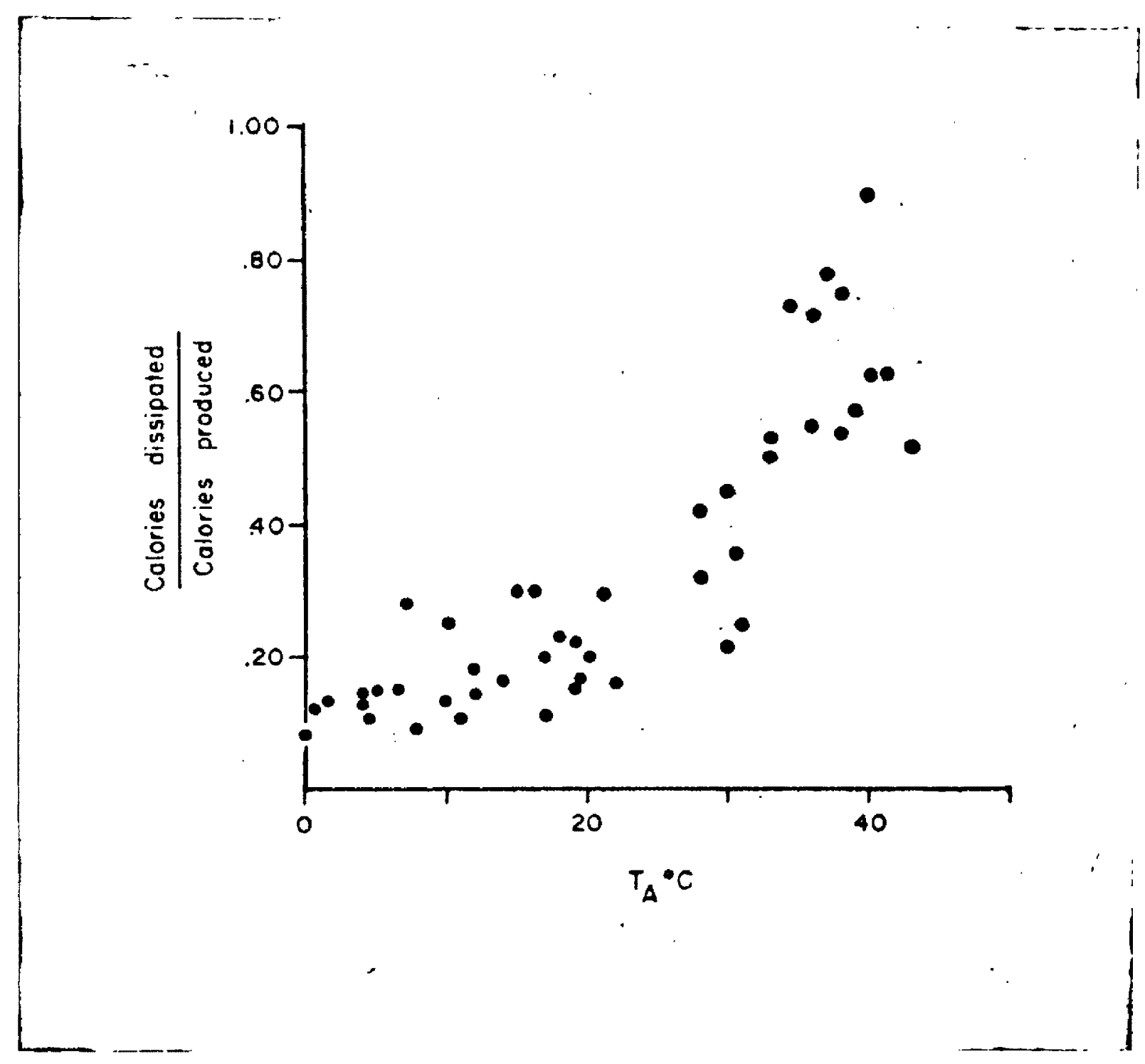

716. 3. Evaporative cooling as a runction of ambient tomperature for sixteen White-talled Pterwigan. 
approxinately $32^{\circ}$. One remined allve for three houra and the other for 20 hours. The other two birds 21 red for, 45 minutes and elght hours but theif body temperatures were not measured. Body temperatures of the five birde wioh 21 red wre not taken.

Body temperetures increased as ambient temperature rose above $38^{\circ} \mathrm{C}$. the upper exitical texperuture (Table I). One Individual at an abient tempereture of $39^{\circ} \mathrm{C}$. had a body temperature of $41.1^{\circ} \mathrm{C}$. and 1ts wetabol1sin rowained conetant, but $h 1 \mathrm{gh}$, throughout the experiwent (roar boura). Three birds at an amblent temperature of $40^{\circ}$ for 20 to 30 alnutes eack had body temperature of between $43.4^{\circ}$ and $44_{.4}^{\circ} \mathrm{C}$. when remored from the notebolio chaber. The motabollaw of each bira had begun to Increase rapialy juat prior to removal. One bird at an amblent temperature of $40^{\circ}$ meintalned a constant metabolie rate for flve houra but its

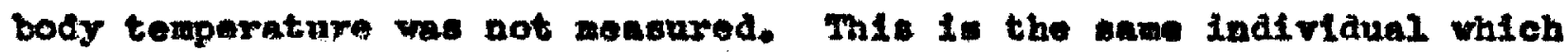
achleved 90\% evaporative effleteney (see Braporat 1ve Water Loss). Body temperatures vere not takes of the three blrds at ambient temperatures above $40^{\circ} C_{0}\left(40.5^{\circ}, 42^{\circ}, 43^{\circ}\right)$, but these blrda also showa the repld increase in wotabolle rates noted sbove. Whe birds at abient temperatures of $41^{\circ}$ and $43^{\circ} \mathrm{C}$. died arter one hour of exposure. All birds exponed to ambient temperatures of $40^{\circ}$ or higher vere panting very replasy lmediately erter removal now the chaber. The neok of each bixd wa bent backward so that 1 ta head rested upon Ita back and the b111 faeed alreetif uprard. BIxds in this condition vere barely able to maintaln theif balence. Panting and pooture of this cort ras never observed in the fleld. 


\section{DrSCUSSIOA}

Oxymen Consumption

The standard metabolle rate of $1.30 \mathrm{ce} \mathrm{O}_{2} / \mathrm{g} \times \mathrm{hr}$ (or $48.8 \mathrm{Kcal} / 2 \mathrm{~h}$ hr) 10 allghtly higher than values predicted from the Brody-Proctor. KIng-Parner and Leelewskl-Dawaon equations (Table 2). Ptarmigan rely hearily upon cemouflege for protection and selection meens to have favored a nearly continuous wolt during the breeding seawon (selomonsen, 1939; Johnnon, 2939 in Host, 2942; personal obs.) enabling the ptarmigan to mateh thelr ohanging habltat rather closely. The high metabolle rate obtained in this study may renect the energy expenditure associated with thls wolt. Such a correlation 1s vell known in many other species though the exact reamon for this remains uncertein (Kine and Farner, 1961 ).

\section{Insulation}

The lover eritleal temperature of $6.5^{\circ}$ to $21.5^{\circ} \mathrm{C}$. for the ptarmlgan in this atudy is quite lov compared to mont birds and only two record have been published of lover values for blrds in surmer plumege, 6० C. for the Black Brant (Brente bernicla) and $-7^{\circ} \mathrm{C}$. for the Northvest Crov (Corrus ceurlnug) (Irring. et al. 1955). The lor ralue for the ptarnigan may be partly related to its hlgh watebolic rate, but 1t appeare malnly to be due to 1 te Lov conductence $(0.036$ to 0.047

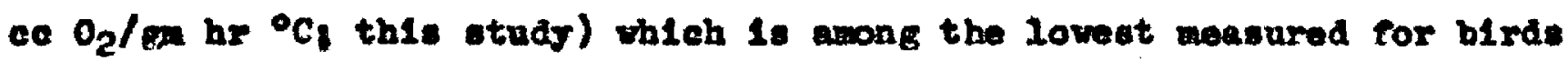
(Horreld e Kessel, 1967). Herreld and Kessel (1967) obtained a sullar velue $\left(0.044\right.$ ce $\mathrm{O}_{2} / \mathrm{en}$ hr ${ }^{\circ} \mathrm{C}$.) for a Rock Ptargigan of stullar veleght in eumier plumege. 


\section{Table 1}

Body Temperatures at Amblent

Tempereturea Outside the Therwoneutral zone

\begin{tabular}{|c|c|c|c|}
\hline & $\begin{array}{l}\text { Ambient } \\
\text { Temp }{ }^{\circ} \mathrm{C} .\end{array}$ & $\begin{array}{c}\text { Body Tewp. } \\
: \text { oct } \\
\end{array}$ & $\begin{array}{l}\text { Tlne of } \\
\text { Exposure Fours }\end{array}$ \\
\hline \multirow[t]{3}{*}{$\begin{array}{l}\text { Amblent temperatures } \\
\text { above the upper } \\
\text { eritleal tomperature }\end{array}$} & $\begin{array}{l}+40 \\
+40\end{array}$ & $\begin{array}{l}44.4 \\
44.2\end{array}$ & $\begin{array}{l}1.2 \\
1.5\end{array}$ \\
\hline & +40 & 43.4 & 1.3 \\
\hline & +39 & 41.4 & 4.0 \\
\hline \multirow[t]{2}{*}{$\begin{array}{l}\text { Anblent temperatures } \\
\text { belov the lower } \\
\text { eritical temperature }\end{array}$} & $\begin{array}{l}-17 \\
-20\end{array}$ & $\begin{array}{l}39.0 \\
32.0\end{array}$ & $\begin{array}{l}4.0 \\
1.8\end{array}$ \\
\hline & -28 & 32.2 & 1.5 \\
\hline
\end{tabular}

1H 1 for each body temperature glven. 


\section{Table 2}

Experinental and Expeoted Metabolle Rates

Vielght $\mathrm{kR} \quad \mathrm{Kanl} / 24 \mathrm{hr}$.

Lesopue Ienourus

Bxpected Matuborlan

Brody Equat1on 1

(a11 birds)

King-Farner Equation

(a21 birde)

Xing-Faner Equation

(birte over $0.2 \mathrm{~kg}$ )

Iestervik1-Dawoon Bquat 1 on 2

(nonpecserine birde)
.326

48.8

.326

43.4

.326

38.3

.326

32.3

.326

34.8

$2_{\text {Bquation from KIng } ~}$ Farner (1961).

${ }^{2}$ Equation from Leqpievek1 * Davson (1967). 
This conductance ralue, though quite lov for aumer birds, would not be adequate to malatein normal body temperatures in winter (ambient temperature reaches h5 $^{\circ} \mathrm{C.}$ ) whout cone1dereble rise (350\%) in watam bol1e rate (F18. 1). Greater ingulation in witer would therefore ceen advantageoul. The consideration that feathere eerve priwarily for fight and do not alept eltber to season or to longltudinal eline (Irving. et 2. 1955( Hart. 2962) 10ses edgency in viex of the sedontary nature of the White-talled Ptarmigan which makes 1to short altitudinal migrations on foot end frequontiy runs frow danger ratber than taking night.

Sagenal changes in Insuletion vere not worsured in this study but Coner (1874) and Grinnell (1900) have mode obeervations sufgestine ouch a change. The insulative value $\left(0.84^{\circ} \mathrm{c} / \mathrm{Keal} / \mathrm{m}^{2} \mathrm{hr}\right)$ obtelnad bs sobolander, et al. (19500, in Hiseh, 1960), for a vinter ptarmigan is elightiy bigher than that obtelned in this study based upon aurmer birda $\left(0.71^{\circ} \mathrm{c} / \mathrm{Kenl} \mathrm{w}^{2} \mathrm{hr}\right)$ but he ald not speelfy which species he used. Herreld s Keasel (1967) found that conductance decreased (Insuration

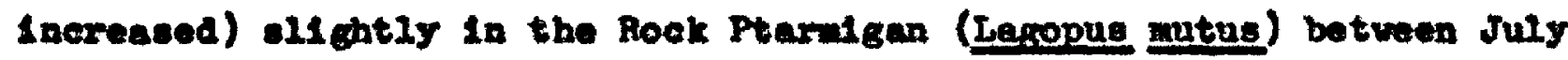
and Iorcaber but only one Individual was moanured in each ones. Data are evaliable for turkers, pleons, and several opecies of passerines Indieating vectonel inoulation ohange (Kendelgh, 2934, Wetwore, 1936, Hart, 2957, 1962, Deveon, 1958, West, 1960, Veghte, 1964).

\section{Evaporative cooling}

Unt11 recently only desert blrde vere thought to be able to evaporate wore than $200 \%$ of thelr potabolic heat. but Laelersk1, et al. 
(1966) have eupplied eridence Indleating that nearly all birds have the eapacity for such eraporative cooling at lov relative humidities. The White-talled Ptarmigan has the lowest efflelency of the epecies neasured oven though the bunldity used was conelderably lowor then that for all other blras. Dlfferences in efflolency in evaporative cooling may be

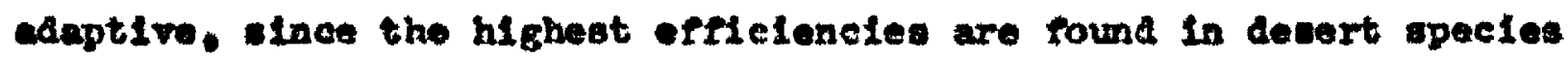
and the lovert in an alpine epectes.

\section{Body Temperature}

The body temperatures obtalned in this study were somethat lover than tbose obtained by other workere (Table 3). The cause of thl. alfference 10 not clear but it could be due to seasonal changes alneo all the previous date vere collected in winter. Irving and Krog (1954) est imated the body temperature of rosting vinter ptarnigen of all throe spectes to $41.0^{\circ}$ to $41.5^{\circ} \mathrm{C}$.

sumer unlte-talled Ptarnigan appeer to maintaln a uniform body tamportire ntar $39.5^{\circ} \mathrm{C}$. over the amblent temperature range rrou $38^{\circ}$ to $-18^{\circ} \mathrm{C}$. Belov $-17^{\circ}$ the ptarmigan cannot malntaln normal body temperature. Veghte and Horreld (1965) found that White-talled Ptarnigan could intain a noraal body temperature at anblent temperature of $-34^{\circ} \mathrm{C}$. in vinter.

The 2ethal body temperature cannot be deternined from the present data. Ptaraigan can withetend a body temperature of $43^{\circ}-44^{\circ} \mathrm{C}$. for at 2east a few minutes but it is not known for bow long nor how much higher the body temperature could 60 whout resulting in permanent danags. 
Birde reating in the dark for one bour or leas at an mblent temperature of 4. C. shoved precipitous increave in metabolie rate and then dled. Blnee three of our birds at an ambient temperature of $40^{\circ} \mathrm{C}$. for 30 minutes or lese undervent a smilar lncrease in metabolic rate. It seems Iikely that they vould also have died vithin one hour if they had not been removed from the chamber sooner. It therefore appears that $40^{\circ} \mathrm{C}$. for one bour or lees is the lethel anblent temperature for nost ptarnigan renting in tho dark. 
Table 3

Body Temperaturea of Ptarmigan

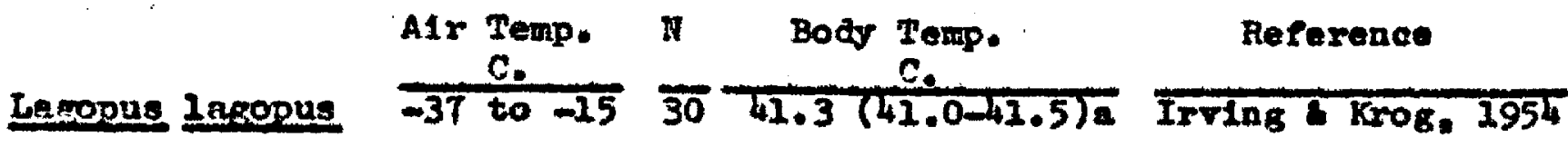

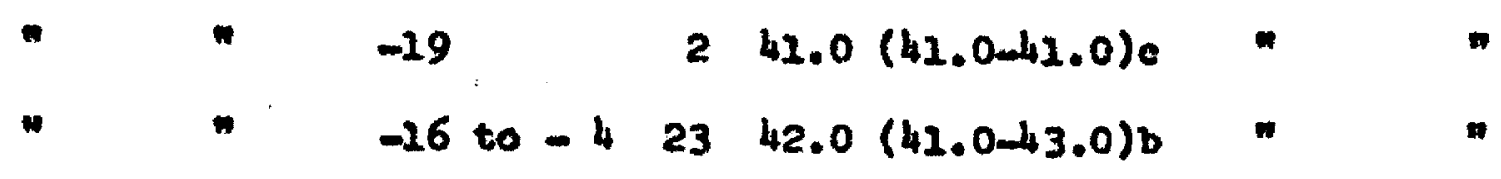

Legopug mutug $\quad 20 \quad 42.3(41.8-42.8)$ "

Lagopus 1eucuras -10 to $-813.41 .5(40.5-42.8)$ e *

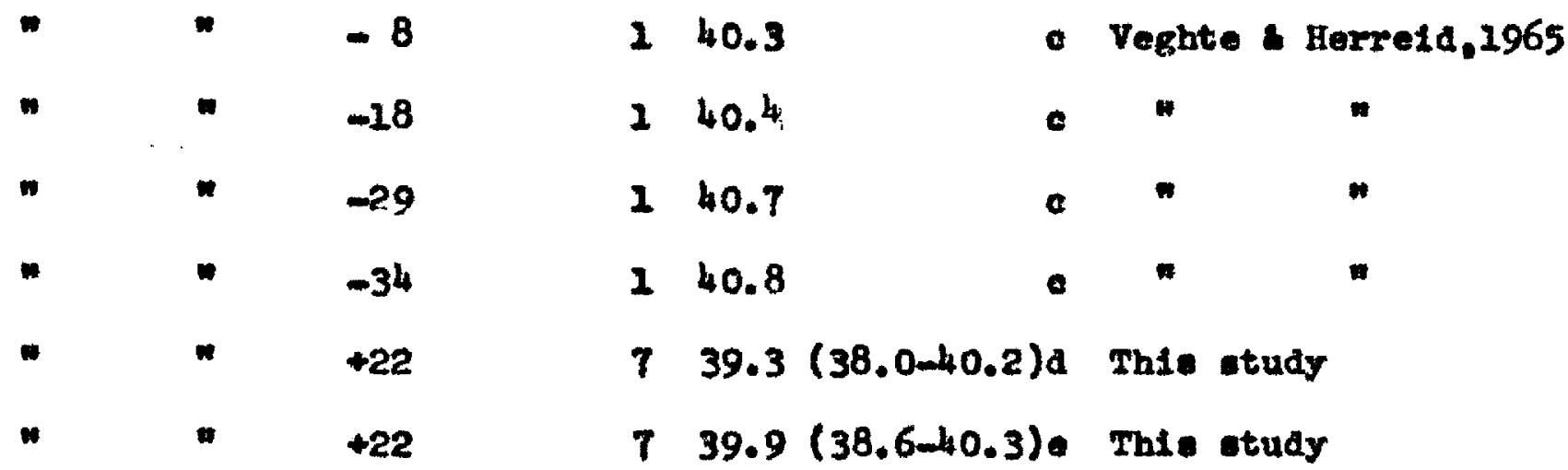

abot. vinter.

b. ohot in night, vinter

e captive birds, vinter

a captive birds, sumer, upon arousel at 8 AM

- captive birds, sumor, der 


\section{EUVIROMMEITAL RELATTONS}

Cold is an important factor in the environment of the White-tailed Ptarmigan in both sumaer and rinter. Results of the present otudy sugnost that this species is vell adapted to these $20 \mathrm{v}$ temperatures. Bince the lover exitical temperature is quite lov and the inoulative value is exceptionally high. In eddition ptaraigan use countermeurrent heet exehango in thelr lego and have teathered reet and both of these sdaptat10ns reduce heat 20 a considerably (Irring and Kros. 1955 ).

On the other hand ptarmigan may not be af vell adapted to high ablant tenperaturea. The eraporative effielency (90\%) is the 10vest value obtained for any bird measured at a lov rapor pressure (2.2 an 48 or a relative humidity of $4 \%$ at $40^{\circ} \mathrm{c}$. ). Hovever, on Logan Pase the relative humidity never dxops below $26 \%$ even whon amblent temperatures betwem $20^{\circ}$ and $32^{\circ}$ C. are reached (choate. 1963a) t th1s corresponds to

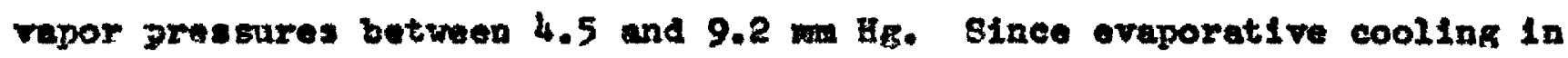
birda is dependent upon the vater vapor prensure gradient between the

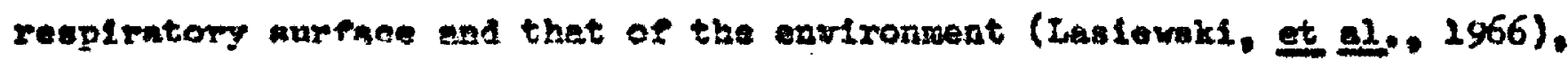
the etrarativo efflelency of a ptarmigan on Logen Puse on a hot dar would be 2 ese than the paximu value obserred in the Inboratory.

The lov evaporative efflefency augsesto that the ptermigan is poofly adepted phyelologleally to alr temperaturea ebore that of Ite body and although the insulation on the dorsum shields coler radiation, the Ineulation on the rest of his body including the legs prevents ragid alselpation of body heat. While at rest in the metabolic chember. the 
bird withotood amblent temperaturea as $\mathrm{blgh}$ as $38^{\circ} \mathrm{C}$. vithout ut111210g apprectable, If any, eaergy for evaporative cooling. One can project that wile at reat in the upine at these aribient temperatures the bird vould remain comfortable. But if they became active in the miday oun (e.8. - foraging) they vould have to frequent ahade and cool areas intermittentiy to diseipete the beat collected during tbis ectivity. Panting way oceur st this time. The relatively heary sumer insulation is apparentiy selected for to wthstand the rather frequent oumer cold periods. such as snow stores, at the expense of limiting tibeir tolermee to the Interaltient warm perlods.

Ptarnigen, therefore. eppear to be adapted to cold environmeata both in vinter and ammer, primar12y becauae of their heav insulation. The presence of ehade and cool areas in certain alfine areas allov the ptarnigan to escape the Intence solar radiation and the hlgh amblent temperatures reaulting from this radiant heat. The cool wheroenvironment prortded by mow and shelter eppears easentiej. to ptarmigra and eajs further meaning to three of the four factors (1.e., regetation type, rook 8120. and anow) suggested as Important in habitat selection by Woeden (In Choate. 2963a). It also appears that cool amblent temperatures shoula be Included an a elth factor in habitat gelection,. Fince habitats apparentiy lacking only thle one factor are also lacking ptainlgan. 
SUMAARY

1. The teraperature regulation of adult White-talled Ptarigan (Lagopue lencurus) vas studied in Iuno through August, 2965.

2. Blyds were captured on Logan Pase at 6,800 to 7,400 reat in Glacler Natlonel Park, Montane, and traneported 18 wiles to Bt. Kary (4,500 foet) where all experimentel work vas done.

3. Oxygen consumpt100, evapoxative vater 10se, and body temperature were weaured over a vide range of mblent temperatures.

4. The standard abobolle rate of $48.8 \mathrm{Keal} / 24 \mathrm{hr}$. $20 \mathrm{r}$ the ptarmigan is alightly higher than expected and way be assoclated with the continuous molt in this epecles.

5. The Lover critleal texperature $\left(6.5^{\circ}\right.$ to $\left.11.5^{\circ} \mathrm{C.}\right)$ to one of the lowert values recorded for birds and ronecte the ptarnalgan's excel- 2eat insulation.

6. The ptarmi gan hat the lovest eraporative efflelency recorded in birde. Differences in efflelency of evaporative coollng way be adaptive, elnce they are correlated with habitat.

7. Amblent temperature may be en important factor in habitat selection In some cases. 


\section{IITERATURE CITED}

Balley. V. and F. U. Balley. 1918. H1Id Anteale of Glacler National Park. Kat Lonal Park Servlce. Vabington. D.C.

Barth, I. K. 1949. Redetemperaturer of rugevaner. Haturea 73. 81-95.

Bradbury. W. C. 2915. Notes on the neating of white-telled ptarnigan In Colorado. Condor 1T. 214-222.

Bump. C.. R. W. Darrow. F. C. Edminster, and W. F. Criseey. 1947. The rufsed frouse - Life history-propogation - anagenent. New York Const. Dept., Albany. $925 \mathrm{pp}$.

Choate. T. S. 1960. Observatione on the reprouluct1m activities of

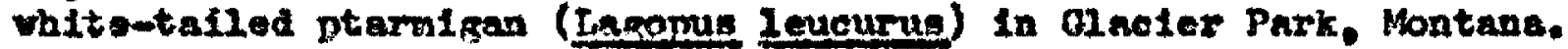
Master"s thesis. University of Montana, M1ssoula.

1963a. Reolory and population dynenies of white-talled ptarmigan (Lefopus Iencurus) in Gieoler Nationel Park. Montank. Doctoral dism eertation. Univeralty of Montane. Hissoula.

1963b. Habltat and population aymaics of whitemtalled ptarmigan In Montena. J. M11d1. Mprt. 27, 684-699.

Clarke, C. H. D. 1936. Muctuations In numbers of ruffea Exouse Bopaga unbeilus (Linne). Nth special reforence to Ontario. Univ. Toronto Studies, Blol. Sertes. Bull. 4I. $228 \mathrm{pP}$.

Coues. F., 1874. Birds of the Horthwest. U. B. Geologleal Burvey. Washington, D.C.

Davson. W. R. 1958. Relation of oxygen consumption ond eveporat Ive water 1083 to temperature in the cardinal. Physiol. 2001. 31. 37 48.

Depoces. F. and 3. B. Hart. 2957. Use of the Peuling oxygen analyzer for meenurement of oxycen consumpt ion of animals in openucirendt ayeteres and in ahort-lag closed-cireult apparatus. I. Appl. Phyalo1. 10, 388-392.

Dorney. R. S. and C. Kabat. 1960. Relation of venther, paranitic disease and hunting to hilsconsin ruered grouse populat lona. Wlsconsin Coneerv. Dept. Teeh. Bull. 20.

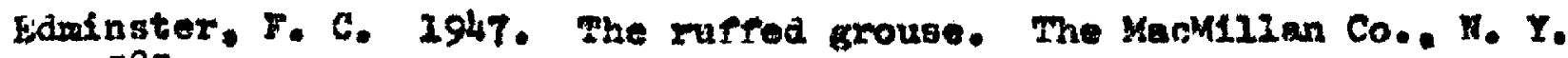
$385 \mathrm{pp}$.

2dwards. J. O. 2957. The pternatgan of Glacler rational Park. Audubon Mas. 59. 252-255. 
Grange. W. B. 1949. The vay to game abundance. Charles scribner'a Bone. I. I.

Grinnell. I. P. 1900. Birde of the Kotzebue Sound reglon. Alaska. Pacific Cat. Arifame I, 1-80.

Hart. J. 8. 195T. C21matio and texperature-induced changes in the energetice of homeotherme. Rev. Cen. B101. 16, 133-174.

1962. Seasonal acclimatimation in four specles of emall w1d birde. Phyasol, Zool. 35, 224-236.

Herre1d, C. P. and B. Keasel. 1967. Therwel conductance in birds and maviana. Comp. Blochena. Phyralol. 21.405-414.

HBglund, I. 1952. Caperca11110 reproduction and cliuate. Flnnish Game Foundation. Heisinki (RLis tatietedilsia Juikaisuja). Fapers on Gawe Researoh 8.

Host. F. 1942. Exrect of 11ght on the molts and sequences of plunage in the 1110 ptarmigan. Auk 59.388403 .

Irving. I. and J. Krog. 1954. Body temperstures of Arotic and aubAret1e birde and masualo. J. Appl. Phrs101. 6, 667-680.

and 1955. Temperature of skin in the Aretie as a regulator of heat. J. Appl. Phre101.7. 355-364.

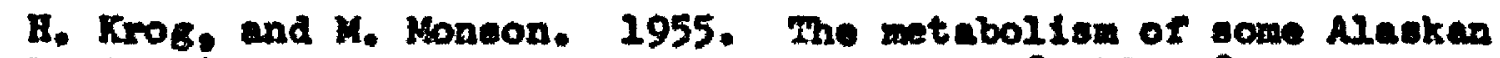
anivels in vinter and sumer. Phys101. Zool. 28, 173-185.

Jendas. D. A. Weteon, and A. R. M11er. 1963. Population studies on red grouse. Lefopus legopus geotious (Lath.) In Nortb-Bast Bcotland, J. Antmal Eool. $32(3) \cdot 317-376$.

Kahl, IY., K, P. 1963. Thermoreguletion in the Wood stork, with special reference to the role of the 1ege. Phys101. 2001.. 36, 141-255.

Kendelgh. 8. c. 193h. The role of environment in the 11 fe of birde. Beol. Honogx. 4, 299m427.

KIng, J. B. and D. S. "Farmer. 1961. Fnorgy metebol1an, therworegulet 104 and body temperature. In Blology and Comparative Phyalology of Blrds (Edited by Marshall, A.J.). Val, 2, Dp. 215-288. Academic Prese. London.

Iack. D. 2966. Population studies of birds. Clarendon Prosa, Oxford. $341 \mathrm{pp}$. 
Larten, J. A. and J. F. Lahey, 2958. Influence of veatber upon a ruffed gronae population. J. H11a1. Kant. 22, 63-70.

Leslewoki, R. C. 1964. Body temperature, heert and breathing rate, and -vaporative vater 108s in humingbirds. Physiol. 2001. 37, 212m223.

A. L. Acoste, and H. H. Bernetein. 1966. Evaporative water Iose in birde-I. Characterietice of the open hov mothod of cetermination, and their relation to estiwntes of therworegulatory ability. Comp. Blochen. Phye101. 19,445-457.

and $U$. R. Davson. 1967. A remexanination of the relation between stendard motabolle rete and body whight in birde. Condor 69. $13-23$.

HLIIer, O. A. D. JenkLns, and A, Vatson. 1966. Heather performence and red grouse populations. J. Appl. Ecol.: 3. 313-326.

MLeb, M. 8. 1960. Heat regulation in the northern bluejey, Crenocitte erigtate bromie. Physiol. Z001. 33, 252-259.

Horan, P. A. P. 1954. The statistieal analysis of game bird records, II. J. Animat Bool. 23. 35-37.

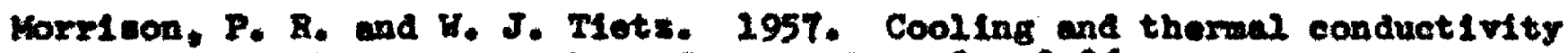
10 throe Alakkan mamals. 3. Mamal., 38, T8-86.

Nethereole-Thowpion, C. and D. Nethersole-mompson, 1939. Some observem tlone on the eaxual 11fe, display and breeding of the red grouse. 8x. B1ras 32. 247. 254.

Parratt, t. F. 1964. Birda of Glacler National Park, Glacier Vatural History Aesoelation, Weat Glaclar. Montana.

Riteey. R. W. and R. Y. Edvards, 1963. Gronse abundance and June temperm eture in Nells Gray Park. Erttioh Columbla. J. Wi2d, Mgmt. 27. $604-606$.

Belomonsen, F. 1939. Moulte and Bequences of Plumeges in the Rock Ptarmigan (Lapopus wutug (Montin)). Haase; Copenrager.

Beholander, P. F., R. Hoek, V. Haltex, F. Johnson, and I. Irving, 1950 . Heat reguietion in sone aret1e and tropleal namals and birds. Biol. Bu11. 99. 237-259.

V. Waltere, R. Hook, and t. Irving. 1950b. Body insulation of some aretic and tropleal mammal and birde. Blol. Bull..99. 225-236. 
Sistonen, I. 2957. The problem of the short-term Ruetuations in numbe of tetroonide in Burepe. Papers on Game Research 19. FInaleb Gan Powalion, Heleinkl. $44 \mathrm{pp}$.

Bvan, I. W. 1952. Some environmental conditions infuencing IIfe at high altitudes. Ecolog 33, 209-121.

Taylor. W. P. and W. T. Maw. 192T. Mamals and Blrde of Mt. RaInier Tetional Park. Netional Park Bervice Washington. D.C.

v. 8. Department of Agriculture. 1941. Yearbook of Agriculture. U. 8 . cort. Printing Orfice. Veahington, D.C.

Veghte, J. H. 1964. Thermal and netabolie reeponse of the gray jay to cold strese. Physilol. 2002.. 3T. 316-328.

and C. F. Herre1d. 2965. Radiometrie determination of reatber Ineulation and motaboliam of Aretio birds. Phralol. Zool. 38. $267-275$.

Verbeek. H. A. M. 2965. Bresalng blolopy. beharior and ecology of the water pipit (Anthos spinolette). Master's Thesis. Univereity of Hontane, Miseoula.

Hest, 0, c. 1960. Seasonal, rariation in the exergy balance of the tree aparrow in relation to migret1on. Auk 7T. 306-329.

Wetwore, A, 1936. The number of contour feathere in paseoriform and roliated birde. Auk $53,259-169$. 